\title{
Motilin: from gastric motility stimulation to hunger signalling
}

Eveline Deloose, Wout Verbeure, Inge Depoortere and Jan Tack*

Abstract $\mid$ After the discovery of motilin in 1972, motilin and the motilin receptor were studied intensely for their role in the control of gastrointestinal motility and as targets for treating hypomotility disorders. The genetic revolution - with the use of knockout models — sparked novel insights into the role of multiple peptides but contributed to a decline in interest in motilin, as this peptide and its receptor exist only as pseudogenes in rodents. The past 5 years have seen a major surge in interest in motilin, as a series of studies have shown its relevance in the control of hunger and regulation of food intake in humans in both health and disease. Luminal stimuli, such as bitter tastants, have been identified as modulators of motilin release, with effects on hunger and food intake. The current state of knowledge and potential implications for therapy are summarized in this Review.

The discovery of motilin in 1972 heralded a new era in gastrointestinal motility research ${ }^{1}$. The involvement of motilin in the regulation of the migrating motor complex (MMC) was identified in dogs in 1975 (REF.') and in humans in $1979\left(\mathrm{REFS}^{3,4}\right)$. Further studies showed that motilin had stimulatory effects on gastric and gallbladder emptying ${ }^{5,6}$. Altered motilin release had been reported in a number of gastrointestinal disorders, but the importance of these changes remains unclear. In 1984, similarities in the motility patterns induced by motilin and by the 14-membered macrolide antibiotic erythromycin A were reported ${ }^{7}$. In 1989, erythromycin A was identified ${ }^{8}$ as a motilin receptor agonist. Erythromycin A belongs to the class of macrolides, a group of molecules consisting of different lactone ring sizes containing one or more deoxy sugars. Subsequent studies showed that many other erythromycin A derivates $^{9}$ (including 12-membered but not 16-membered macrolides) act as motilin receptor agonists. In the 1990s, several motilin receptor agonists were developed and studied for the treatment of gastrointestinal hypomotility disorders, but disappointing outcomes emerged from clinical trials with the motilide ABT-229. These results were attributed to receptor desensitization owing to the long half-life of the drug, wrong dose selection (which might have decreased the selectivity profile of the macrolide for the neural motilin receptor) or suboptimal patient selection ${ }^{10}$. These negative outcomes, as well as the lack of a functional motilin receptor in rodents (which is important for studies in knockout models), have hampered the further development of motilin ligands for therapeutic applications in humans.
In 2016, motilin was identified as a key hunger signal from the gastrointestinal tract ${ }^{11}$. This discovery has redefined the potential physiological roles of this peptide and has opened a broad new range of applications for motilin receptor ligands or modulators of motilin secretion, including tastants. This Review provides a comprehensive overview of the current state of knowledge regarding the gastrointestinal hormone motilin, its receptor and motilin receptor agonists together with the role of motilin in normal physiology and pathophysiology.

\section{Motilin}

In 1967, duodenal alkalinization was discovered to stimulate the motility of denervated transplanted pouches of the gastric corpus in $\operatorname{dogs}^{12}$. This effect was suspected to be the result of the release of a hormone, which was subsequently isolated in 1972 and named motilin ${ }^{1,13}$. Porcine and human motilin share the same 22-amino acid sequence ${ }^{13,14}$. Meanwhile, the peptide has been isolated from many species, with the exception of rats and mice, in which motilin exists only as a pseudogene ${ }^{15,16}$. Indeed, in general, the rodent gastrointestinal tract has proved to be refractory to motilin and erythromycin A both in vitro and in vivo ${ }^{8,17}$. Nevertheless, some studies have reported an excitatory effect of motilin on gastric motility, brain neurons and food intake in rodents ${ }^{16}$. Rodent-specific differences in gastrointestinal regulation might explain these different effects of motilin, but given that high concentrations of motilin were used in these studies, nonspecific effects cannot be excluded. On the basis of this divergence in evolution, we speculate that ghrelin might be the surrogate of motilin in rodents. 


\section{Key points \\ - Motilin is a gastrointestinal hormone produced in the small intestine; during the fasting state, plasma levels of motilin fluctuate and induce gastric contractions to signal hunger via a cholinergic pathway. \\ - The cyclic release of endogenous motilin in the fasting state is mainly regulated by duodenal acidification and bile acids. \\ - Postprandially, the secretion of motilin is modulated by the presence of macronutrients and the release of other gut hormones (insulin, somatostatin, pancreatic polypeptide and secretin). \\ - Exogenously administered motilin or motilin agonists accelerate gastric emptying via high-sensitivity neural receptors and low-sensitivity muscular receptors and increase lower oesophageal sphincter pressure but have no effect on colonic motility. \\ - Stimulatory effects of motilin have been observed on hunger ratings, gallbladder emptying and glucose-induced insulin secretion. \\ - Targeting the motilin receptor has therapeutic potential to treat hypomotility disorders, modulate hunger and affect glucose metabolism.}

The human motilin gene $(9 \mathrm{~kb})$ is localized on chromosome 6 and is encoded by 5 exons, of which exon I and exon $\mathrm{V}$ encode only the $5^{\prime}$ untranslated region and the $3^{\prime}$ untranslated region, respectively ${ }^{18}$. The motilin precursor is composed of a signal peptide ( 25 amino acids in length), motilin itself and so-called motilinrelated peptide ( 65 amino acids in length $)^{19}$. The plasma half-life of motilin is approximately $4 \mathrm{~min}^{20}$. Motilin belongs to the ghrelin-motilin-related peptide family and shares $36 \%$ sequence similarity with ghrelin ${ }^{21}$.

Motilin is mainly produced by the enteroendocrine cells of the duodenum. Evidence suggests that motilin is co-stored with ghrelin in the same secretory granules of human and pig duodenal cells ${ }^{22}$. Motilin has also been identified in neurons in the myenteric plexus ${ }^{23}$.

The $\mathrm{NH}_{2}$ terminus has been identified as an essential region for the biological activity of motilin, while the $\mathrm{COOH}$-terminal part stabilizes the $\mathrm{NH}_{2}$ terminus ${ }^{24,25}$. Moreover, the C-terminus of motilin is involved in desensitization and internalization of its receptor ${ }^{26}$.

\section{Regulation of motilin release}

No cell line has been created to study the secretion of motilin at a cellular level; thus, the mechanisms underlying the control of its release remain obscure. A dosedependent stimulatory effect of carbachol on motilin release from isolated canine intestinal cells, inhibited by atropine, implies the presence of muscarinic receptors on the motilin cell membrane ${ }^{27}$. TABLE 1 summarizes the physiological factors influencing motilin secretion in humans.

\section{Fluctuations in motilin levels}

During the interdigestive state. In the fasting state, plasma levels of motilin fluctuate in parallel with phase III contractions of the MMC (see subsequent section $)^{4,28-31}$. The MMC is an aborally propagating contractility complex of the upper gastrointestinal tract during the fasting state, characterized by three different phases: phase I is a period of motor quiescence, phase II displays progressively increasing motor activity and phase III has the highest contractile activity and can start in either the stomach or small intestine. Findings in dogs that both spontaneous and induced phase III contractions were associated with a peak in plasma levels of motilin, often occurring at the time of duodenal phase III, led researchers to believe that the increase in endogenous motilin was a consequence of the strong phase III contractions squeezing motilin out of its enteroendocrine cells ${ }^{32}$. However, this theory was refuted by results showing that the motilin plasma peak occurred before the start of phase III contractions and only if phase III started from the stomach but not with a duodenal origin ${ }^{30,31}$. Moreover, in humans, phase III contractions induced by either erythromycin A or ghrelin are not associated with an increase in plasma levels of motilin ${ }^{33,34}$. Thus, how fluctuations of endogenous motilin release are regulated remains unclear to date.

Because the gastric response to duodenal alkalinization led to the discovery of motilin ${ }^{12}$, the effect of manipulation of duodenal $\mathrm{pH}$ on motilin release has been of prime interest. Although several authors ${ }^{28,35,36}$ confirmed that intraduodenal alkalinization produced an increase in plasma levels of motilin in dogs, studies in humans failed to show a similar phenomenon ${ }^{37,38}$. Instead, acidification of the duodenum increases motilin release both in vivo and in vitro in humans ${ }^{38-41}$. During the MMC, duodenal $\mathrm{pH}$ fluctuates, which is considered to reflect the secretory component of the MMC, as it has been shown that phase III coincides with peak duodenal, pancreatic and gastric secretions $s^{42,43}$. During phase I, duodenal $\mathrm{pH}$ remains stable and is alkaline. A drop in $\mathrm{pH}$ occurs during phase II as a result of an increase in gastric output, with fluctuations between $\mathrm{pH} 2.0$ and $\mathrm{pH}$ 7.5. Duodenal $\mathrm{pH}$ remains stable and alkaline during phase III owing to stimulation of bicarbonate release in the duodenum ${ }^{42,43}$. Patients with duodenal peptic ulcers have a long MMC cycle despite increased plasma levels of motilin ${ }^{44}$

The presence of bile in the duodenum is another factor that influences motilin release during the fasting state. Gallbladder emptying during the interdigestive state occurs in synchrony with phase III contractions of the MMC and increases the release of motilin ${ }^{45-49}$. Administration of taurocholate, a bile acid, stimulated the release of motilin in an ex vivo perfusion study ${ }^{50}$. Future research is needed to evaluate how gastric acid and bile acids, resulting from gastric emptying and gallbladder contraction, interact to regulate motilin release from the duodenum.

During the postprandial state. The release of motilin after a meal depends on the nutrient composition of the meal. Equicaloric oral administration of protein, fat, carbohydrates and a mixed meal showed diverse effects on the release of motilin in humans ${ }^{38}$. A small reduction occurred after the administration of glucose, but lipids markedly increased the release of motilin, with levels remaining elevated for $60 \mathrm{~min}$ after administration ${ }^{38}$. The inhibitory effect of glucose and the stimulatory effect of lipids on motilin release have been confirmed by several other studies ${ }^{37,50-52}$. When glucose or lipids were administered intravenously, the same response occurred as when these nutrients were given orally ${ }^{52}$. One study reported that intragastric, but not intraduodenal, administration of lipids increased plasma levels of 
Table 1 | Factors influencing motilin release in humans

\begin{tabular}{llr}
\hline Factors influencing motilin & $\begin{array}{l}\text { Plasma concentration } \\
\text { of motilin }\end{array}$ & Refs \\
\hline Acidification of the duodenum & $\uparrow$ & $37-41,53$ \\
\hline Alkalization of the duodenum & $\downarrow$ & $37-40$ \\
\hline Bile & $\uparrow$ & $47-50,53$ \\
\hline Protein & $\uparrow$ and no effect & 38,50 \\
\hline Fat & $\uparrow$ & $37-39,50,52,53$ \\
\hline Glucose & $\downarrow$ & $38,50-52,54,165,166$ \\
\hline Bitter compounds & $\downarrow$ & $55-57$ \\
\hline Insulin & $\downarrow$ & $50,53,54,164$ \\
\hline Somatostatin & $\downarrow$ & 66,67 \\
\hline Ghrelin & No effect & 33 \\
\hline Gastrin & No effect & 50 \\
\hline Cholecystokinin & No effect & 27,67 \\
\hline Pancreatic polypeptide & $\downarrow$ & 78 \\
\hline Secretin & $\downarrow$ & 67,79 \\
\hline Glucagon-like peptide 1 & No effect & 81 \\
\hline
\end{tabular}

motilin ${ }^{37}$. However, in another study, administration of a high dose of lipids directly into the duodenum did stimulate motilin release $\mathrm{e}^{53}$. Ingestion of a protein meal has been reported to increase or have no effect on plasma levels of motilin ${ }^{38,50}$. Mixed meals have been reported to increase, decrease or have no effect on plasma levels of motilin $^{37,38,50-52,54}$.

As well as the macronutrient composition of the meal, non-nutrients also influence motilin release. Intragastric administration of the bitter compounds denatonium benzoate or quinine-hydrochloride substantially decreased endogenous plasma levels of motilin in healthy female volunteers ${ }^{55-57}$. The presence of bitter taste receptors on enteroendocrine cells and the effect of bitter compounds on the release of gastrointestinal hormones have been shown by several groups ${ }^{58-61}$. It is therefore likely that bitter taste receptors are also expressed on the motilin-producing cell or that the release of other peptides from enteroendocrine cells expressing bitter taste receptors alters motilin release. To date, no data are available on the receptor expression profile of motilin-producing cells, but many other gut peptides are able to affect motilin secretion.

In conclusion, food components have a complex effect on motilin release. The finding that a water load alone also induced a profound effect on motilin release further complicates the interpretation of the findings, as it suggests that gastric distension or lowering of the osmolarity in the duodenum might affect motilin release as well ${ }^{62}$.

\section{Effect of endogenous hormones}

Somatostatin. Somatostatin is secreted by D cells located in the gastric antrum and to a lesser extent in the duodenum ${ }^{63}$. Somatostatin inhibits acid secretion and the release of several peptide hormones ${ }^{64}$. Intravenous administration of somatostatin in humans and dogs inhibited motilin release $\mathrm{e}^{20,65-67}$. Moreover, the plasma concentration of somatostatin peaks before the occurrence of a duodenal phase III contraction, when no motilin peaks occur ${ }^{66}$. Administration of the somatostatin analogue octreotide inhibited the release of motilin in an ex vivo perfused model of the canine jejunum pretreated and denervated with tetrodotoxin, suggesting a direct inhibitory effect of somatostatin on motilin release ${ }^{68}$.

Ghrelin. The gastrointestinal hormone ghrelin was discovered in 1999 (REF. ${ }^{21}$ ). Although motilin and ghrelin show considerable amino acid sequence similarity, ghrelin does not bind to the motilin receptor ${ }^{69}$. Ghrelin requires a post-translational esterification of the third serine residue with octanoic acid by ghrelin $O$-acyltransferase for its activation ${ }^{70}$. Ghrelin is produced by P/D1 cells in the oxyntic mucosa and stimulates food intake, adipogenesis and gastric emptying ${ }^{71}$. In humans, endogenous levels of ghrelin neither fluctuate together with the phases of the MMC nor correlate with motilin levels ${ }^{72,73}$. Indeed, exogenous administration of ghrelin in healthy volunteers does not alter plasma concentrations of motilin ${ }^{33}$.

Gastrin. Gastrin, which is produced by G cells located in the gastric antrum and duodenum, stimulates the production of gastric acid by parietal cells ${ }^{74}$. Intravenous administration of gastrin in humans and dogs had no effect on motilin release $\mathrm{e}^{50,75}$.

Cholecystokinin. Cholecystokinin is produced by the I cells in the small intestine and is involved in the stimulation of gallbladder emptying, pancreatic secretion, delay of gastric emptying and inhibition of food intake $e^{74}$. Intravenous administration of cholecystokinin in dogs and humans did not alter the release of motilin ${ }^{67,75}$. Stimulation of canine isolated intestinal cells with cholecystokinin did not increase motilin release in vitro ${ }^{27}$.

Pancreatic polypeptide. Pancreatic polypeptide is produced by pancreatic polypeptide cells in the endocrine pancreas and inhibits pancreatic secretion and gastrointestinal motility ${ }^{76}$. Administration of exogenous pancreatic polypeptide in a dosage corresponding to postprandial levels decreased plasma levels of motilin in both dogs and humans $s^{29,77,78}$.

Secretin. Secretin is produced by S cells located in the duodenum and jejunum and inhibits the release of gastric acid while stimulating the production of bicarbonate and secretion of bile ${ }^{74}$. Exogenous administration of secretin decreased the release of motilin in humans, which might be mediated via the concomitant release of somatostatin or the stimulation of pancreatic bicarbonate secretion ${ }^{67,79}$. Secretin administration had no effect on motilin release in $\operatorname{dogs}^{75}$.

Glucagon-like peptide 1. Glucagon-like peptide 1 is an incretin hormone produced by the L cells of the intestine. Glucagon-like peptide 1 is released after food intake and inhibits gastric emptying ${ }^{80}$. Intravenous administration of glucagon-like peptide 1 in both healthy individuals and patients with irritable bowel syndrome did not affect plasma concentrations of motilin ${ }^{81}$. 


\section{Motilin receptor}

The orphan G protein-coupled receptor GPR38, originally isolated from the thyroid gland, was identified as the motilin receptor in 1999 (REF. ${ }^{82}$ ). Two alternatively spliced forms of this receptor exist: GPR38A is the typical (seven transmembrane domains) biologically active form; GPR38B is a truncated (five transmembrane domains) biologically inactive form. The motilin receptor is structurally related to the ghrelin receptor (overall amino acid identity 51.6\%), neurotensin receptor 1 (32.7\%), neurotensin receptor 2 (34.1\%) and the orphan GPR39 receptor $(28.7 \%)^{83}$.

Motilin receptor density in humans is highest in the gastroduodenal region and decreases distally ${ }^{84}$. By contrast, the highest motilin receptor density in rabbits is found in the colon ${ }^{85}$. Receptor-binding studies show that motilin receptors are present on smooth muscle cell membranes but also in neural synaptosomes of the rabbit and human antrums ${ }^{86-89}$. Immunofluorescence studies confirmed the expression of the motilin receptor in longitudinal muscle myenteric plexus preparations and cultured myenteric neurons of the guinea pig ileum ${ }^{23}$.

Both ends of the second extracellular loop of the motilin receptor contain binding sites for motilin, which are not critical for erythromycin $\mathrm{A}^{90,91}$. A common binding site for motilin and erythromycin A is located in the third transmembrane region of the motilin receptor ${ }^{92}$. The motilin receptor is susceptible to desensitization ${ }^{26,93,94}$. The phosphorylated motilin receptor recruits $\beta$-arrestin 2 with greater affinity than $\beta$-arrestin 1. These multifunctional adaptor proteins bind to the phosphorylated receptor and disrupt the interaction between the receptor and $G$ proteins to target the receptor to clathrin-coated pits ${ }^{95}$. The ligandreceptor complex is subsequently sorted to recycling endosomes that traffic the motilin receptor back to the plasma membrane. Internalization and resensitization of the motilin receptor are agonist dependent. A higher degree of internalization and less recycling of the motilin receptor were observed with ABT-229 than with erythromycin $\mathrm{A}^{96}$. The strong desensitization properties

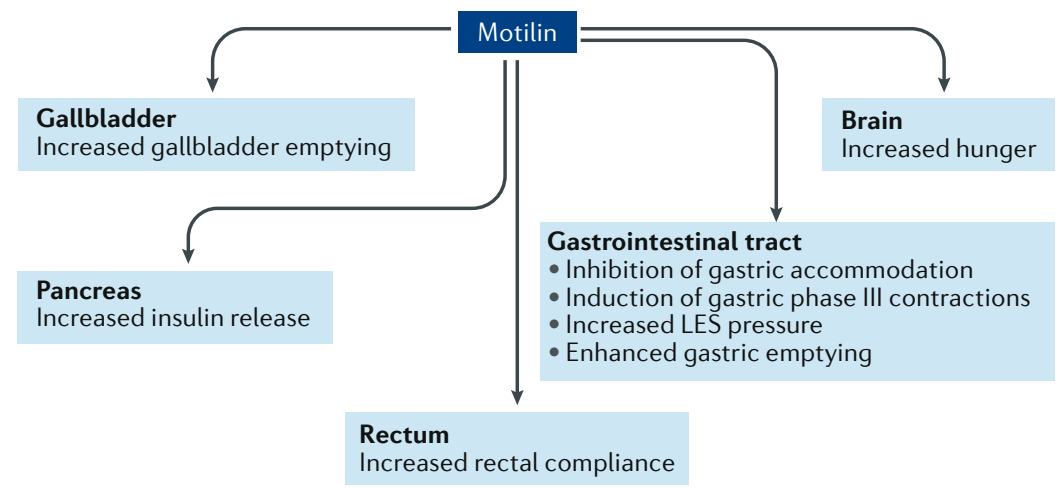

Fig. 1 | Main biological functions of motilin. The main production site of motilin is the small intestine. In the gastrointestinal tract, motilin increases the pressure of the lower oesophageal sphincter (LES), initiates gastric phase III contractions of the migrating motor complex, stimulates gastric emptying, inhibits gastric accommodation and increases rectal compliance. Insulin secretion and gallbladder emptying are both increased by motilin. Finally, motilin also activates regions in the brain involved in the homeostatic and hedonic regulation of food intake. of the motilide ABT-229 might have contributed to its failure in clinical trials ${ }^{10}$.

\section{Motilin and gastrointestinal physiology}

In the 1980s and 1990s, motilin was studied intensively for its effects on gastrointestinal motility ${ }^{3-5,29,30,32,34,46,97-105}$. Since 2016, the implication of motilin in the control of hunger and food reward has generated a renewed interest in motilin and its receptor ${ }^{11,106,107}$. FIGURE 1 provides an overview of the biological functions of motilin.

\section{Mechanism of action on contractility}

Functional in vitro contractility studies using rabbit and human antral smooth muscle strips showed that motilin enhanced post-ganglionic cholinergic neurotransmission at low doses and activated a smooth muscle receptor at high doses ${ }^{108-110}$. In isolated rabbit gastric and intestinal smooth muscle cells, motilin initiated a transient contraction involving Gaq-mediated inositol-1,4,5trisphosphate $\left(\operatorname{Ins}(1,4,5) \mathrm{P}_{3}\right)$-dependent $\mathrm{Ca}^{2+}$ release and a sustained Gaq-mediated and $\mathrm{Ga}_{13}$-mediated cascade involving $\mathrm{RHO}$ kinase and protein kinase $\mathrm{C}$-dependent inhibition of myosin light chain phosphatase ${ }^{111}$.

The motilin receptor is also expressed in the nodose ganglion of the Japanese house musk shrew (Suncus murinus $)^{112}$. In vitro, motilin increased the gastric but not the jejunal afferent nerve firing rate in these animals ${ }^{113}$. These findings substantiate the observations in some studies of reduced effects of motilin after vagotomy ${ }^{114}$.

The presence of motilin receptors in the brain ${ }^{112,115,116}$, thyroid and bone marrow ${ }^{82}$ indicates that motilin is a multifunctional hormone, although its role in these regions remains to be explored.

\section{The migrating motor complex}

Motilin received its name from the initial observation that it stimulates motor activity of fundic pouches in $\operatorname{dogs}^{12}$. The whole motilin molecule was first synthesized in 1975 (REF. ${ }^{117}$ ). In 1976, intravenous administration of motilin in fasted dogs was found to induce phase III of the MMC ${ }^{2,118}$. This finding was later confirmed in humans ${ }^{3}$. The interdigestive motility pattern in the upper gastrointestinal tract was first observed by Boldyreff in 1905, who found that the stomach of starving dogs exhibited alternating periods of strong contractions and absolute quiescence ${ }^{119}$. These periods of activity were further described and classified as phase I, phase II and phase III ${ }^{120}$. In 1969 , electrical activity during these periods of gastrointestinal motility was identified and found to migrate caudally over the entire length of the small bowel ${ }^{121}$. Further studies showed that the MMC moves from the stomach to the terminal ileum over a period of 1.5-2.0 hours and is interrupted by nutrient intake ${ }^{122,123}$.

Endogenous plasma levels of motilin fluctuate during the different phases of the MMC in dogs, with a peak in plasma concentration of motilin before phase III $^{28}$. After duodenectomy in the same species, plasma levels of motilin no longer fluctuate, and no antral phase III contractions occur ${ }^{124}$. In 1980, plasma levels of motilin were reported to fluctuate in humans in accordance with MMC activity ${ }^{4}$. FIGURE 2 illustrates the relationship 
between plasma levels of motilin and MMC activity in a healthy human individual. Interestingly, only phase III contractions that start in the stomach are motilindependent ${ }^{29}$. This finding has been confirmed by other researchers ${ }^{30,31}$, although motilin peaks before duodenal phase III contractions have been reported when these were preceded by strong gastric contractions not qualifying as gastric phase III $^{30}$. Plasma levels of motilin increase by $35 \%$ from phase I to phase III if phase III has a gastric origin ${ }^{72}$.

In contrast to motilin, endogenous ghrelin does not fluctuate with the phases of the MMC, although exogenous ghrelin administration can induce premature gastric phase III contractions in humans ${ }^{33}$. In S. murinus, a synergistic effect was observed between ghrelin and motilin for the coordination of the $\mathrm{MMC}^{125}$. Evaluating whether a similar relationship between ghrelin and motilin exists in humans would be interesting.

\section{Lower oesophageal sphincter}

The lower oesophageal sphincter (LES) is a highpressure zone located between the stomach and the oesophagus to prevent regurgitation of stomach content to the oesophagus. Both the LES and the oesophagus show contractility patterns that are related to the $\mathrm{MMC}^{126,127}$. Maximum pressures of the LES occur during late phase II and phase III, whereas minimum values are present during phase I of the MMC. These changes in LES contractility might contribute to preventing gastrooesophageal reflux episodes in healthy individuals during strong gastric contractions ${ }^{126}$. The oesophagus shows bursts of non-deglutitive contractions during the $15 \mathrm{~min}$ before the onset of phase III ${ }^{127}$. In humans, intraduodenal acidification increased both endogenous motilin levels and LES pressure ${ }^{128}$. Administration of motilin or motilin receptor agonists increased LES pressure in both healthy volunteers and patients with gastro-oesophageal

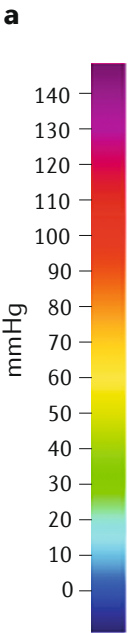

Phase III Phase I

Phase II

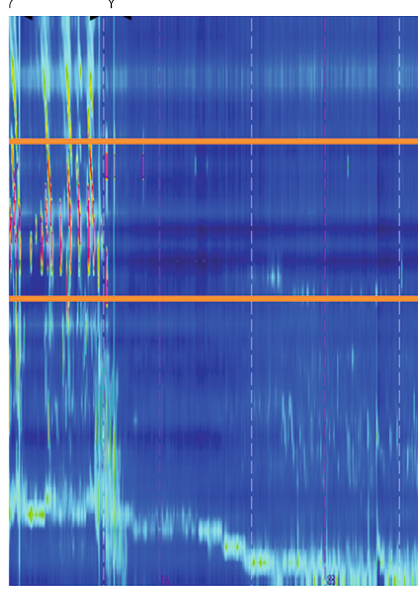

B1

B2

B3

0

b

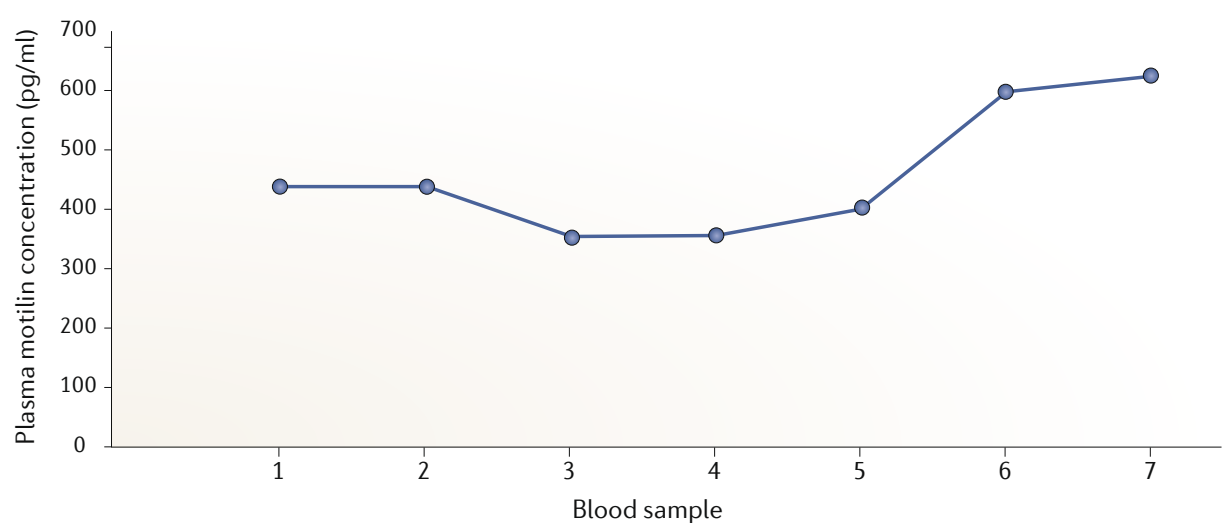

Fig. 2 | Fluctuation of plasma levels of motilin during the different phases of the migrating motor complex. a | Antroduodenal motility was measured using a high-resolution manometry catheter (ManoScan 360, Sierra Scientific Instruments) in a healthy female volunteer (21 years old with a BMI of $22 \mathrm{~kg} / \mathrm{m}^{2}$ ). The catheter was positioned with measuring channels in the fundus, antrum and proximal part of the duodenum after an overnight fast. The measurement continued for the duration of one complete migrating motor complex (MMC) cycle. Duration of the different phases is indicated above the pressure plot tracing. Two gastric phase III contractions were measured. B values on the $y$ axis represent times of blood sample collection over the full MMC cycle. $\mathbf{b}$ | Blood samples were collected every 10 min in icechilled LiHep tubes containing aprotinin $(500 \mathrm{kJU} / \mathrm{ml})$ between two consecutive phase III contractions. Samples were centrifuged at $4{ }^{\circ} \mathrm{C}$ for $10 \mathrm{~min}$ at $3,000 \mathrm{~g}$ and analysed by a radioimmunoassay for motilin ${ }^{72}$. Plasma levels of motilin decrease during phase I and phase II and increase during phase III contractions. 
reflux disease (GERD) $)^{129-134}$. The therapeutic potential of motilin receptor agonists in GERD treatment is largely unexplored.

\section{Gastric accommodation}

After consumption of a meal, the fundic region of the stomach relaxes to accommodate the increase in volume without an increase in pressure ${ }^{135}$. Administration of motilin or erythromycin A substantially reduces the accommodation reflex in humans by increasing the proximal gastric tone $e^{103,136}$. Decreased gastric accommodation leads to early satiation and decreased nutrient volume intake, which suggests motilin and its receptor could be targets for controlling satiation and food intake ${ }^{136,137}$. Patients with functional dyspepsia have impaired gastric accommodation to a meal, which is associated with symptoms of early satiety ${ }^{138}$. However, baseline plasma levels of motilin and the effect on gastric compliance after motilin administration have been reported to be similar among patients with functional dyspepsia and healthy control individuals ${ }^{139}$, although detailed studies with simultaneous measurement of interdigestive motility are lacking. By contrast, patients with functional dyspepsia, but not healthy volunteers, experienced an increased sensation of nausea after the administration of motilin, possibly reflecting hypersensitivity to tension generated by gastric contractions ${ }^{139}$. However, these measurements were performed during the fasting state. Evaluating the role of motilin on gastric compliance after food consumption in patients with functional dyspepsia would be an interesting area of research.

\section{Gastric emptying}

After digestion of a meal, food remnants are emptied into the duodenum, where nutrient absorption occurs. One of the first studies on the effect of motilin on gastric emptying reported that administration of the motilin analogue 13-norleucine-motilin delayed the rate of gastric emptying of a liquid meal in humans ${ }^{140}$. A later study ${ }^{97}$, with the endogenous form of motilin in a higher dosage, reported an increase in the rate of gastric emptying of a solid meal. The effect of both motilin forms on human fundic muscle strips was similar, however, as both increased contractile responses in vitro ${ }^{141}$. Other studies have confirmed the stimulatory effect of motilin and erythromycin A on gastric emptying rate in healthy volunteers and in patients with idiopathic and diabetic gastroparesis, scleroderma, anorexia nervosa and intestinal pseudoobstruction ${ }^{5,99,142-150}$. The effect of high doses of erythromycin A (200-250 mg) on gastric emptying seems to be independent of the vagus nerve, as erythromycin A accelerated gastric emptying in patients who had undergone a vagotomy ${ }^{98,151}$.

Notably, the relationship between acceleration of gastric emptying and symptom improvement is weak in patients with gastroparesis ${ }^{152}$. Given that high doses of erythromycin A have even been reported to induce nausea in patients with dyspepsia and gastroparesis $^{139,153}$, low doses of motilin receptor agonists should be used that selectively activate neural instead of smooth muscle receptors in the stomach to stimulate gastric emptying and in the vagus to promote appetite and reduce nausea ${ }^{154}$.

\section{Colonic motility}

Motilin receptors are expressed in the colon of humans, but their density in the colon is substantially lower than that in the antroduodenal region ${ }^{82,84,110,155}$. Motilin receptor agonists had no effect on contractility of human isolated colonic tissue nor did they increase colonic motility in healthy volunteers or patients with chronic obstipation (severe or complete constipation) ${ }^{110,156,157}$. Administration of motilin in healthy volunteers increased rectal compliance without influencing rectal sensations ${ }^{158}$.

\section{Gallbladder emptying}

Administration of erythromycin A increased gallbladder emptying in both healthy individuals and patients with gallstones ${ }^{159}$. Moreover, gallbladder motility was normalized after erythromycin A administration in patients with impaired gallbladder emptying ${ }^{159}$. Exogenous administration of motilin increased gallbladder emptying in a dose-dependent manner ${ }^{6,160}$.

\section{Role of motilin in glucose metabolism}

Motilin not only regulates gastrointestinal motility but also influences plasma levels of insulin. During the interdigestive state in dogs, plasma levels of insulin fluctuate together with plasma levels of motilin without altering glucose levels ${ }^{161}$. Administration of exogenous motilin substantially increased insulin levels through a vagal cholinergic muscarinic pathway but did not affect glucose levels ${ }^{161,162}$. A similar effect (that is, an increase) of basal and glucose-induced insulin secretion was observed in healthy volunteers and in patients with type 2 diabetes mellitus treated orally with erythromycin A for 1 or 4 weeks, accompanied by a decrease in glucose levels ${ }^{163}$. Further research on the anti-diabetic effect and mechanism of action of motilin agonists in type 2 diabetes mellitus seems warranted.

While motilin influences insulin secretion, insulin also alters motilin secretion. In humans, an inverse correlation has been shown between motilin and glucose and motilin and insulin during the postprandial state $^{50,54,164}$. However, neither glucose nor insulin affects motilin secretion from human duodenal mucosa biopsy samples, indicating that their effect on motilin release is indirect. The inhibitory effect of insulin on motilin release in humans seems to be glucose-independent, as shown by using an euglycaemic glucose clamp ${ }^{164}$. Administration of xylitol, a low-caloric sweetener with minimal effects on insulin secretion, increased rather than decreased plasma levels of motilin ${ }^{165}$. Our group has also shown that administration of acesulfame $\mathrm{K}$, a noncaloric sweetener with no effect on insulin secretion, did not alter plasma levels of motilin ${ }^{166,167}$. Elevated plasma levels of motilin have been reported in patients with diabetes mellitus compared with healthy controls ${ }^{51,101}$. Future research should explore the mechanisms behind the inhibitory effect of insulin on motilin secretion and how this relationship is disturbed in patients with diabetes mellitus ${ }^{51,101}$. 


\section{Regulation of food intake and hunger}

By 1833, the sensation of hunger was associated with the physiology of the stomach ${ }^{168}$. In the same century, strong contractions of the stomach were postulated to be responsible for the sensation of hunger ${ }^{169}$. This idea was further confirmed early in the 20th century ${ }^{169,170}$. In 1975, exogenous motilin administration was reported to induce 'hunger contractions' ${ }^{2}$, but the link between motilin and hunger was largely forgotten after these early observations. Notably, these contractions have not been established to be directly responsible for the sensation of hunger.

To date, ghrelin is the only gastrointestinal hormone classified as an orexigenic hormone. Exogenous administration of ghrelin increases food intake in both rats and humans ${ }^{171,172}$. Moreover, plasma levels of ghrelin increase before food intake ${ }^{173-175}$. Interestingly, plasma levels of ghrelin are substantially lower in patients with obesity than in healthy individuals ${ }^{176,177}$.

In 2016, our group reported that hunger scores in humans fluctuate with the different phases of the MMC and peak when phase III has a gastric origin (FIG. 3). Moreover, a positive correlation was found between endogenous plasma levels of motilin and hunger scores in the interdigestive state ${ }^{11}$ (FIG. 4). Hunger peaks could also be generated by the administration of exogenous motilin or erythromycin $\mathrm{A}^{11,106}$. The stimulation of hunger by motilin agonism is driven via a cholinergic pathway, as administration of atropine abolished the
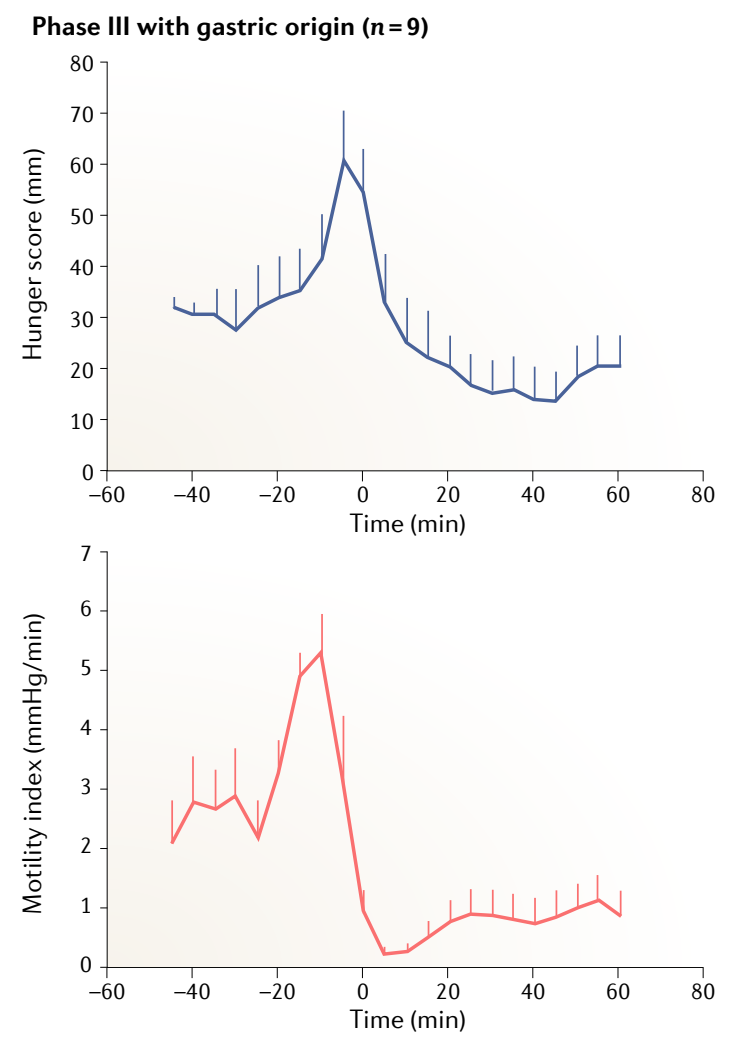

Fig. 3 | Relationship between interdigestive motility and hunger ratings. Mean hunger ratings $(100 \mathrm{~mm}$ visual analogue scales) and antral motility index in nine healthy volunteers are shown, with a spontaneous phase III with gastric origin. Gastric phase III motor activity and hunger ratings are closely correlated. orexigenic effect of erythromycin $\mathrm{A}^{106}$. Contractions induced by either neostigmine (an acetylcholinesterase inhibitor) or ghrelin did not markedly increase hunger sensations during the fasted state, indicating that only motilin-induced gastric contractions or motilin itself increases hunger scores ${ }^{11}$. Erythromycin A has also been shown to modulate brain regions related to homeostatic and hedonic control of appetite and feeding ${ }^{107}$. Further support for a role of motilin in the control of food intake was provided by a study showing that a low dose of erythromycin A stimulated voluntary meal requests in healthy volunteers ${ }^{106}$. However, total caloric intake from an ad libitum buffet meal after erythromycin A administration did not differ from placebo, nor were motilin levels of plasma increased before spontaneous meal requests ${ }^{175}$. Taken together, these findings illustrate that motilin has a complex role in the regulation of food intake, with a main role in determining the return of hunger and initiation of meals.

Intragastric administration of the bitter compounds denatonium benzoate or quinine-hydrochloride substantially decreased plasma levels of motilin ${ }^{55-57}$. In healthy controls, intragastric administration of denatonium benzoate also inhibited gastric accommodation, which was associated with increased satiation and decreased nutrient volume tolerance ${ }^{178}$. However, plasma levels of motilin were not measured in this study.

\section{Role of motilin in pathophysiology}

Plasma levels of motilin have been described to be altered in several conditions with disturbed gastrointestinal motility. In patients with functional dyspepsia with delayed gastric emptying, plasma levels of motilin did not fluctuate as normal during the interdigestive state, and gastric phase III contractions were absent ${ }^{179}$. In patients with diabetic gastroparesis, plasma levels of motilin were elevated but still fluctuating during the interdigestive state, although antral phase III activity was absent ${ }^{51,101}$. In patients with morbid obesity, increased plasma levels of motilin were found during the MMC, with a loss of motilin plasma peaks before phase III and a suppression of gastric phase III contractions ${ }^{180}$. Hunger scores were reduced in patients with obesity but could be restored after administration of erythromycin $\mathrm{A}^{180}$. A year after Roux-en-Y gastric bypass surgery, plasma concentrations of motilin normalized to levels of healthy volunteers ${ }^{180}$.

To date, there are no reports on plasma levels of motilin in patients with anorexia nervosa. In patients with unexplained loss of appetite, gastric phase III contractions are suppressed, but plasma levels of motilin were not measured in this study ${ }^{11}$. A similar observation to that seen in patients with obesity has been reported for elderly individuals (that is, increased plasma levels of motilin during the MMC, with a loss of motilin plasma peaks before phase III and a suppression of gastric phase III contractions) ${ }^{181,182}$. Patients with irritable bowel syndrome have been described to have increased plasma levels of motilin, although the cyclic variation with the MMC was still present in this population ${ }^{183}$. One study reported that plasma levels of motilin were increased only in patients with diarrhoea-predominant irritable 

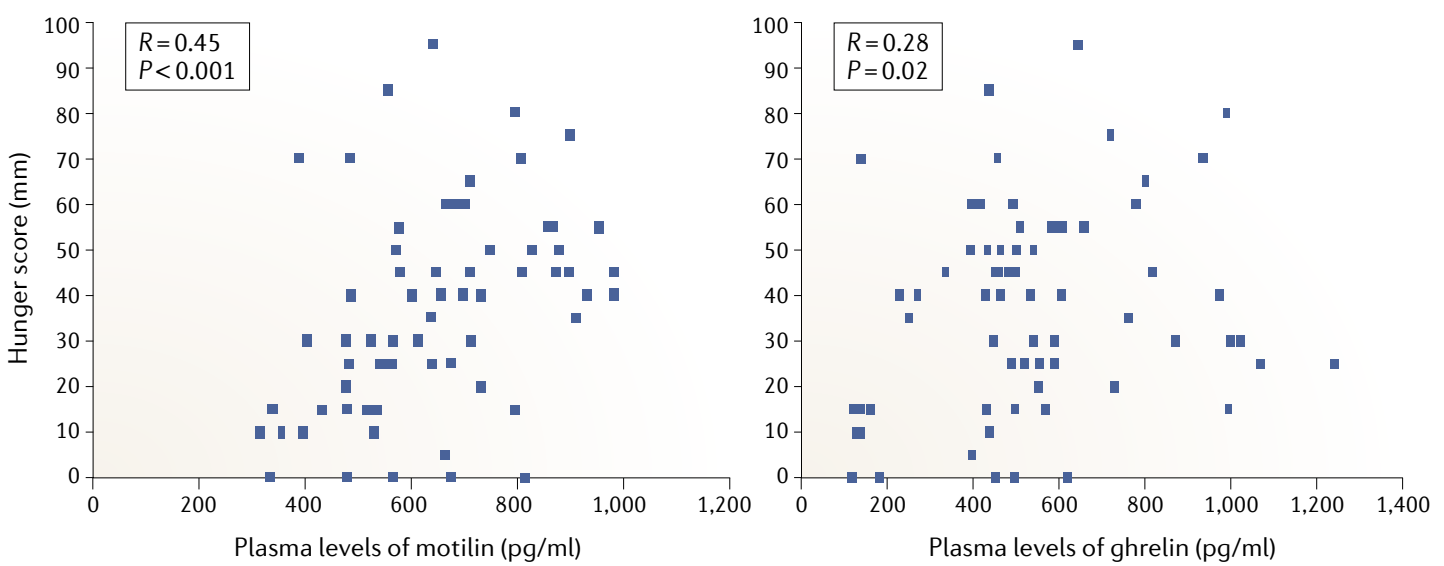

Fig. 4 | Relationship between interdigestive hunger ratings and plasma levels of hormones. The relationship between hunger score (100 $\mathrm{mm}$ visual analogue scales) during the spontaneous migrating motor complex cycle and plasma levels of motilin (left panel) and ghrelin (right panel) in nine healthy volunteers is shown. Plasma levels of motilin, but not ghrelin, are significantly correlated with hunger ratings.

bowel syndrome ${ }^{184}$. A decrease in plasma levels of motilin has been reported in patients with long-standing idiopathic constipation and in patients with GERD ${ }^{185-187}$. TABLE 2 summarizes changes in motilin levels in different diseases. The implication of altered plasma levels of motilin in these conditions is still unclear.

\section{Motilin receptor agonists and antagonists}

The effects of motilin on gastrointestinal motility, hunger and glucose metabolism identify the hormone and its receptor as interesting targets for the treatment of several clinical conditions. Motilin receptor agonists could be used to accelerate gastric emptying in patients with gastroparesis, to stimulate insulin secretion in patients with type 2 diabetes mellitus and to enhance LES pressure in patients with GERD. Moreover, motilin receptor agonists could also be used as appetite stimulants. Motilin antagonists, on the other hand, could improve impaired gastric accommodation and nutrient tolerance, for example, in patients with functional dyspepsia.

\section{Erythromycin A}

Erythromycin A, a macrolide antibiotic, induces gastric phase III contractions of the $\mathrm{MMC}^{7}$. Furthermore, intravenous administration of erythromycin A induces gastric phase III contractions in humans without increasing endogenous levels of motilin ${ }^{34}$. Phase III contractions induced by erythromycin A do not differ substantially from spontaneous phase III contractions, except for having a longer duration of antral phase III contraction ${ }^{34}$.

Direct stimulation of the motilin receptor by erythromycin A was proven by receptor-binding studies and in vitro contractility studies in the presence of a motilin receptor antagonist ${ }^{8,188,189}$. Studies in HEK-293 cells expressing the cloned motilin receptor confirmed that erythromycin A is a motilin agonist ${ }^{82}$. Notably, only low dosages of intravenously administered erythromycin A $(40 \mathrm{mg})$ induce gastric phase III contractions, whereas high dosages ( $200 \mathrm{mg}$ and $350 \mathrm{mg}$ ) induce strong antral contractions that do not migrate caudally ${ }^{100}$. Low doses of erythromycin A activate an intrinsic or vagal cholinergic pathway, whereas high dosages directly activate a muscular receptor ${ }^{104}$. Erythromycin A has proved to be a useful prokinetic for the treatment of gastroparesis in short-term studies ${ }^{99,144-146}$. It might also be beneficial for the treatment of GERD, as it increases LES pressure and decreases the number of reflux episodes when administered intravenously ${ }^{133,190-192}$. Azithromycin, another macrolide antibiotic, has also been shown to activate the motilin receptor and has a similar effect on gastric emptying as erythromycin $\mathrm{A}^{193,194}$. Acid reflux episodes and oesophageal acid exposure were reduced in patients with GERD after treatment with azithromycin ${ }^{195}$. However, the antibiotic properties and ability of erythromycin A and related macrolides to induce QT prolongation make these agents unsuitable candidates for the long-term treatment of gastroparesis ${ }^{196}$.

\section{Motilides}

The findings with erythromycin A prompted the development of the so-called motilides, that is, derivatives of erythromycin A without antibacterial activity but with good motilin receptor activity ${ }^{197}$. ABT-229 was shown to increase gastric emptying in healthy volunteers and dogs and to bind directly to the motilin receptor ${ }^{198-200}$. However, treatment with ABT-229 did not relieve the gastrointestinal symptoms of patients with functional dyspepsia or type 1 diabetes mellitus with or without delayed gastric emptying compared with placebo ${ }^{201,202}$. There was also no improvement of reflux symptoms in patients with GERD ${ }^{203}$. These results might indicate that other populations or subpopulations of patients should be selected or that the dose of ABT-229 was too high to provide symptom relief. Indeed, ABT-229 might have induced adverse effects on gastric accommodation and worsening of the symptoms by stimulating not only neural but also smooth muscle motilin receptors at the fairly high doses used ${ }^{10}$. Despite having a half-life of 20 hours, ABT-229 was dosed twice daily, which might have promoted desensitization of the motilin receptor ${ }^{93,96,204}$.

KC 11458 stimulated gastric emptying in dogs and healthy volunteers but did not improve emptying in patients with diabetes mellitus ${ }^{205}$. Only GM-611 (mitemcinal) has been reported to accelerate gastric emptying 
Table 2 | Conditions with altered plasma motilin levels

\begin{tabular}{|llllr|}
\hline Condition & $\begin{array}{l}\text { Fasting } \\
\text { plasma level } \\
\text { of motilin }\end{array}$ & $\begin{array}{l}\text { Normal fluctuation } \\
\text { of motilin levels } \\
\text { with MMC }\end{array}$ & $\begin{array}{l}\text { Gastric } \\
\text { phase III }\end{array}$ & Refs \\
\hline Idiopathic gastroparesis & Normal & Absent & Absent & 179 \\
\hline Diabetic gastroparesis & $\uparrow$ & Normal & Absent & 51,101 \\
\hline Obesity & $\uparrow$ & Absent & $\downarrow$ & $180,231,232$ \\
\hline Old age & $\uparrow$ & Absent & $\downarrow$ & 181,182 \\
\hline Irritable bowel syndrome & $\uparrow$ & Normal & NS & 183,184 \\
\hline Duodenal ulcer & $\uparrow$ & Normal & $\downarrow$ & 44 \\
\hline Idiopathic constipation & $\downarrow$ & NS & NS & 185,186 \\
\hline Gastro-oesophageal reflux & $\downarrow$ & NS & NS & 187 \\
\hline
\end{tabular}

MMC, migrating motor complex; NS, not studied

in a phase II study in patients with gastroparesis, but the drug was not advanced to phase III $^{206}$.

\section{Small-molecule motilin receptor agonists}

Another class of motilin receptor agonists is derived from a benzylpiperazine molecular structure ${ }^{207,208}$. Camicinal is one of these motilin receptor agonists ${ }^{209}$. This compound binds directly to the motilin receptor, increases gastrointestinal contractility and enhances gastric emptying in healthy volunteers and feed-intolerant critically ill patients ${ }^{210-215}$. A phase II trial in patients with Parkinson disease showed that camicinal induced rapid absorption of L-DOPA and improved Parkinson disease symptoms, probably through decreased variability in speed of delivery of the drug to the duodenum for absorption ${ }^{216}$. Camicinal has a short half-life and unlike motilin induces long-lasting facilitation of cholinergic activity in the human antrum without inducing desensitization, making it an interesting candidate for the treatment of gastroparesis ${ }^{110,209}$. Similar long-lasting activity has previously been observed in the rabbit antrum with camicinal and erythromycin $\mathrm{A}^{109,210}$. A phase II trial evaluating camicinal in patients with diabetic gastroparesis showed symptomatic benefit with the lower dose ranges of the drugs, while the higher doses were most effective in enhancing gastric emptying ${ }^{217}$. The drug has not yet advanced to phase III studies.

The oligopeptide atilmotin increased gastric emptying without affecting colonic filling or transit ${ }^{218}$. It also increased LES pressure but disrupted oesophageal peristalsis ${ }^{130}$. RQ-00201894, another small molecule agonist, binds to the motilin receptor and has been shown to increase antral contractions in human smooth muscle strips through a cholinergic pathway ${ }^{219}$. The oligopeptide SK-896 binds with similar affinity to the motilin receptor as motilin and contracted smooth muscle in in vitro preparations of the rabbit gastrointestinal tract with the same pharmacological profile as $\operatorname{motilin}^{220}$. In dogs, SK-896 induced interdigestive migrating contractions $^{221}$. Moreover, SK-896 improved gastrointestinal motility in postoperative ileus in $\operatorname{dogs}^{222,223}$. The effects on gastrointestinal motility in healthy human volunteers were less pronounced ${ }^{224}$. DS- $3801 \mathrm{~b}$ is the latest nonmacrolide, selective motilin receptor agonist to be developed. In a phase I study in healthy individuals, DS-3801b accelerated gastric emptying 225 . Of these agents, only camicinal has been studied in large clinical trials.

\section{Motilin receptor antagonists}

MA-2029, GM-109, TZP-201 and RWJ-68023 are all motilin receptor antagonists ${ }^{226-229}$. In dogs, MA-2029 inhibited gastrointestinal motility induced by motilin without affecting gastric emptying ${ }^{230}$. TZP-201 reduced motilin-induced contractions of the colon in S. murinus ${ }^{228}$. In humans, RWJ-68023 antagonized the tonic effect of motilin on the proximal stomach ${ }^{229}$. None of these antagonists have been advanced to large clinical trials, at least in part because of a lack of established end points (patient-reported outcomes) and issues with patient selection and magnitude of therapeutic effect.

Studies with bitter tastants have shown that it is possible to inhibit motilin release by activating chemosensory receptors on the motilin cell ${ }^{5-57}$. This approach should be explored further, including studies with other tastants and the effects of repeated administration.

\section{Conclusions}

The notion that motilin is a gastrointestinal hormone involved in only stimulation of gastrointestinal motility needs to be revised. Its potential role in the regulation of food intake and glucose metabolism deserves further attention. The fluctuation in plasma levels of motilin during the fasting state and the variable outcome on motilin levels after meal ingestion demand standardized protocols to evaluate the physiological role of endogenous motilin. In vitro studies should further characterize the neuropeptide and chemosensory receptors that regulate motilin release, as these findings might explain altered plasma levels of motilin in disease states.

In the past, the development of successful motilin receptor agonists has been hampered by the rapid desensitization of its receptor. Future candidate motilin receptor agonists should be tested for their ability to stimulate the motilin receptor, desensitize the motilin receptor and facilitate cholinergic neural contractile responses instead of smooth muscle contractions (which might not only enhance gastric emptying but also reduce symptoms of nausea in patients with gastroparesis by facilitating hunger signalling).

Luminal stimuli have the potential to alter motilin release, as shown by the inhibitory effect of bitter tastants on motilin release and hunger signalling. Exploring this pathway holds potential for designing totally different approaches to altering motilin signalling for treatment of gastrointestinal diseases or disorders of appetite and food intake. Motilin and ghrelin share many of the same characteristics, but their involvement in gastrointestinal motility, food intake and glucose metabolism is still very different. Future research should evaluate the relationship between these two peptides.

In conclusion, this Review summarizes the main findings of motilin research from the previous and current century and shows that further research is warranted to fully characterize the physiological role of the gastrointestinal hormone motilin.

Published online: 23 January 2019 
1. Brown, J. C., Cook, M. A. \& Dryburgh, J. R. Motilin, a gastric motor activity-stimulating polypeptide: final purification, amino acid composition, and C-terminal residues. Gastroenterology 62, 401-404 (1972).

2. Itoh, Z., Aizawa, R. \& Takeuchi, S. in Proc. 5th Int. Symp. on Gastrointestinal Motility (ed. Vantrappen, G.) 48-55 (Typoff-Press, Belgium, 1975)

3. Vantrappen, G. et al. Motilin and the interdigestive migrating motor complex in man. Dig. Dis. Sci. 24 497-500 (1979)

4. Peeters, T. L., Vantrappen, G. \& Janssens, J. Fasting plasma motilin levels are related to the interdigestive motility complex. Gastroenterology 79, 716-719 (1980).

5. Peeters, T. L. et al. Effect of motilin on gastric emptying in patients with diabetic gastroparesis. Gastroenterology 102, 97-101 (1992).

6. Luiking, Y. C. et al. Motilin induces gall bladder emptying and antral contractions in the fasted state in humans. Gut 42, 830-835 (1998).

7. Itoh, Z., Nakaya, M., Suzuki, T., Arai, H. \& Wakabayashi, K. Erythromycin mimics exogenous motilin in gastrointestinal contractile activity in the dog. Am. J. Physiol. 247, G688-G694 (1984).

8. Peeters, T. et al. Erythromycin is a motilin receptor agonist. Am. J. Physiol. 257, G470-G474 (1989).

9. Depoortere, I. et al. Structure-activity relation of erythromycin-related macrolides in inducing contractions and in displacing bound motilin in rabbit duodenum. Neurogastroenterol. Motil. 1, 150-159 (1989).

10. Tack, J. \& Peeters, T. What comes after macrolides and other motilin stimulants? Gut 49, 317-318 (2001).

11. Tack, J. et al. Motilin-induced gastric contractions signal hunger in man. Gut 65, 214-224 (2016)

12. Brown, J. C. Prescence of a gastric motor-stimulating property in duodenal extracts. Gastroenterology 52, 225-229 (1967)

13. Schubert, H. \& Brown, J. C. Correction to the amino acid sequence of porcine motilin. Can. J. Biochem. 52 7-8 (1974).

14. De Clercq, P. et al. Purification and amino acid sequence of human motilin isolated from a motilin containing liver metastasis. Regul. Pept. 55, 79-84 (1995).

15. He, J., Irwin, D. M., Chen, R. \& Zhang, Y. P. Stepwise loss of motilin and its specific receptor genes in rodents. J. Mol. Endocrinol. 44, 37-44 (2010).

16. Sanger, G. J., Holbrook, J. D. \& Andrews, P. L. The translational value of rodent gastrointestinal functions: a cautionary tale. Trends Pharmacol. Sci. 32, 402-409 (2011).

17. Depoortere, I. et al. Comparison of the gastroprokinetic effects of ghrelin, GHRP-6 and motilin in rats in vivo and in vitro. Eur. J. Pharmacol. 515, 160-168 (2005).

18. Yano, H. et al. Exon-intron organization, expression, and chromosomal localization of the human motilin gene. FEBS Lett. 249, 248-252 (1989).

19. Dea, D., Boileau, G., Poitras, P. \& Lahaie, R. G. Molecular heterogeneity of human motilinlike immunoreactivity explained by the processing of prepromotilin. Gastroenterology 96, 695-703 (1989).

20. Mitznegg, P. et al. Pharmacokinetics of motilin in man Gastroenterology 72, 413-416 (1977).

21. Kojima, M. et al. Ghrelin is a growth-hormonereleasing acylated peptide from stomach. Nature $\mathbf{4 0 2}$, 656-660 (1999).

22. Wierup, N. et al. Ghrelin and motilin are cosecreted from a prominent endocrine cell population in the small intestine. J. Clin. Endocrinol. Metab. 92. 3573-3581 (2007)

23. $\mathrm{Xu}, \mathrm{L}$. et al. Evidence for the presence of motilin ghrelin, and the motilin and ghrelin receptor in neurons of the myenteric plexus. Regul. Pept. 124, 119-125 (2005)

24. Macielag, M. J. et al. Synthesis and in vitro evaluation of [Leu 13]porcine motilin fragments. Peptides 13 565-569 (1992)

25. Peeters, T. L. et al. D-Amino acid and alanine scans of the bioactive portion of porcine motilin. Peptides 13 , 1103-1107 (1992).

26. Mitselos, A., Depoortere, I. \& Peeters, T. L. Delineation of the motilin domain involved in desensitization and internalization of the motilin receptor by using full and partial antagonists. Biochem. Pharmacol. 73, 115-124 (2007).

27. Poitras, P., Dumont, A., Cuber, J. C. \& Trudel, L. Cholinergic regulation of motilin release from isolated canine intestinal cells. Peptides 14, 207-213 (1993).

28. Lee, K. Y., Chey, W. Y., Tai, H. H. \& Yajima, H. Radioimmunoassay of motilin. Validation and studies on the relationship between plasma motilin and interdigestive myoelectric activity of the duodenum of dog. Am. J. Dig. Dis. 23, 789-795 (1978)

29. Janssens, J., Vantrappen, G. \& Peeters, T. L. The activity front of the migrating motor complex of the human stomach but not of the small intestine is motilin-dependent. Regul. Pept. 6, 363-369 (1983).

30. Bormans, V. et al. In man, only activity fronts that originate in the stomach correlate with motilin peaks. Scand. J. Gastroenterol. 22, 781-784 (1987).

31. Boivin, M. et al. Plasma motilin variation during the interdigestive and digestive states in man. Neurogastroenterol. Motil. 2, 240-246 (1990).

32. Sarna, S. et al. Cause-and-effect relationship between motilin and migrating myoelectric complexes. Am. J. Physiol. 245, G277-G284 (1983).

33. Tack, J. et al. Influence of ghrelin on interdigestive gastrointestinal motility in humans. Gut 55, 327-333 (2006).

34. Tomomasa, T., Kuroume, T., Arai, H., Wakabayashi, K. \& Itoh, Z. Erythromycin induces migrating motor complex in human gastrointestinal tract. Dig. Dis. Sci. 31, 157-161 (1986)

35. Dryburgh, J. R. \& Brown, J. C. Radioimmunoassay for motilin. Gastroenterology 68, 1169-1176 (1975).

36. Fox, J. E.. Track, N. S. \& Daniel, E. E. Relationship of plasma motilin concentration to fat ingestion, duodenal acidification and alkalinization, and migrating motor complexes in dogs. Can. J. Physiol. Pharmacol. 59, 180-187 (1981)

37. Collins, S. M. et al. Changes in plasma motilin concentration in response to manipulation of intragastric and intraduoduenal contents in man. Can. J. Physiol. Pharmacol. 59, 188-194 (1981).

38. Mitznegg, P. et al. Release of motilin in man. Scand. J. Gastroenterol. Suppl. 39, 53-56 (1976).

39. Mitznegg, P. et al. Release of motilin after duodenal acidification. Lancet 1, 888-889 (1976).

40. Strunz, U. et al. Acid releases motilin from human duodenum in vitro. Acta Hepatogastroenterol. (Stuttg.) 24, 456-457 (1977).

41. Bloom, S. R. et al. Release of VIP, secretin and motilin after duodenal acidification in man. Acta Hepatogastroenterol. (Stuttg.) 25, 365-368 (1978).

42. Woodtli, W. \& Owyang, C. Duodenal pH governs interdigestive motility in humans. Am. J. Physiol. 268 G146-G152 (1995)

43. Vantrappen, G. R., Peeters, T. L. \& Janssens, J. The secretory component of the interdigestive migrating motor complex in man. Scand. J. Gastroenterol. 14, 663-667 (1979).

44. Kusano, M. et al. Disturbed initiation of gastric interdigestive migrating complexes despite high plasma motilin levels in patients with low gastric $\mathrm{pH}$ Dig. Dis. Sci. 43, 1697-1700 (1998)

45. Romanski, K. W., Peeters, T. L., Bormans, V., Vantrappen, G. R. \& Janssens, J. Interdigestive fluctuations of plasma bile acid concentration: relation to interdigestive motility pattern. Hepatogastroenterology 34, 24-27 (1987)

46. Stolk, M. F. et al. Motor cycles with phase III in antrum are associated with high motilin levels and prolonged gallbladder emptying. Am. J. Physiol. 264, G596-G600 (1993).

47. Svenberg, T., Nilsson, I., Samuelson, K. \& Welbourn, R. D. Studies on the causal relationship between gall-bladder emptying and motilin release in man. Acta Chir. Scand. Suppl. 520, 59-61 (1984).

48. Qvist, N. et al. Increases in plasma motilin follow each episode of gallbladder emptying during the interdigestive period, and changes in serum bile acid concentration correlate to plasma motilin. Scand. J. Gastroenterol. 30, 122-127 (1995).

49. Hellstrom, P. M., Nilsson, I. \& Svenberg, T. Role of bile in regulation of gut motility. J. Intern. Med. 237, 395-402 (1995)

50. Saito, S. et al. Regulation of motilin secretion in the postprandial state in man. Endocrinol. Jpn. 27 (Suppl. 1), 157-162 (1980)

51. Imura, H., Seino, Y., Mori, K., Itoh, Z. \& Yanaihara, N. Plasma motilin levels in normal subjects and patients with diabetes mellitus and certain other diseases. Fasting levels and responses to food and glucose. Endocrinol. Jpn. 27 (Suppl. 1), 151-155 (1980).

52. Christofides, N. D., Bloom, S. R., Besterman, H. S., Adrian, T. E. \& Ghatei, M. A. Release of motilin by ora and intravenous nutrients in man. Gut 20, 102-106 (1979).

53. Jenssen, T. G., Burhol, P. G., Jorde, R., Florholmen, J. $\&$ Lygren, I. Radioimmunoassayable plasma motilin in man. Secretagogues, insulin-induced suppression, renal removal, and plasma components. Scand. J. Gastroenterol. 19, 717-723 (1984).

54. Funakoshi, A., Ho, L. L., Jen, K. L., Knopf, R. $\&$ Vinik, A. I. Diurnal profile of plasma motilin concentrations during fasting and feeding in man Gastroenterol. Jpn. 20, 446-456 (1985).

55. Deloose, E. et al. Intragastric infusion of denatonium benzoate attenuates interdigestive gastric motility and hunger scores in healthy female volunteers. Am. J. Clin. Nutr. 105, 580-588 (2017).

56. Deloose, E., Corsetti, M., Van Oudenhove, L., Depoortere, I. \& Tack, J. Intragastric infusion of the bitter tastant quinine suppresses hormone release and antral motility during the fasting state in healthy female volunteers. Neurogastroenterol. Motil. 30, e13171 (2018).

57. Iven, J. et al. Intragastric quinine administration decreases hedonic eating in healthy women through peptide-mediated gut-brain signaling mechanisms. Nutr. Neurosci. https://doi.org/10.1080/1028415x. 2018.1457841 (2018).

58. Avau, B. \& Depoortere, I. The bitter truth about bitter taste receptors: beyond sensing bitter in the oral cavity. Acta Physiol. (Oxf.) 216, 407-420 (2016).

59. Kim, K. S., Egan, J. M. \& Jang, H. J. Denatonium induces secretion of glucagon-like peptide-1 through activation of bitter taste receptor pathways.

Diabetologia 57, 2117-2125 (2014).

60. Chen, M. C., Wu, S. V., Reeve, J. R. Jr \& Rozengurt, E. Bitter stimuli induce $\mathrm{Ca}^{2+}$ signaling and CCK release in enteroendocrine STC-1 cells: role of L-type voltagesensitive $\mathrm{Ca}^{2+}$ channels. Am. J. Physiol. Cell Physiol. 291, C726-C739 (2006)

61. Wu, S. V. et al. Expression of bitter taste receptors of the T2R family in the gastrointestinal tract and enteroendocrine STC-1 cells. Proc. Natl Acad. Sci. USA 99, 2392-2397 (2002).

62. Christofides, N. D. Importance of the jejunal hormone motilin. J. Clin. Pathol. Suppl. (Assoc. Clin. Pathol.) 8, 51-57 (1978)

63. Penman, E. et al. Distribution and characterisation of immunoreactive somatostatin in human gastrointestinal tract. Regul. Pept. 7, 53-65 (1983).

64. Morisset, J. Somatostatin: one of the rare multifunctional inhibitors of mammalian species. Pancreas 46, 8-18 (2017).

65. Mori, K., Seino, Y., Itoh, Z., Yanaihara, N. \& Imura, H. Motilin release by intravenous infusion of nutrients and somatostatin in conscious dogs. Regul. Pept. 1, 265-270 (1981).

66. Peeters, T. L., Janssens, J. \& Vantrappen, G. R. Somatostatin and the interdigestive migrating motor complex in man. Regul. Pept. 5, 209-217 (1983).

67. Jenssen, T. G., Haukland, H. H., Florholmen, J. Jorde, R. \& Burhol, P. G. Evidence of somatostatin as a humoral modulator of motilin release in man. A study of plasma motilin and somatostatin during intravenous infusion of somatostatin, secretin, cholecystokinin, and gastric inhibitory polypeptide. Scand. J. Gastroenterol. 21, 273-280 (1986).

68. Poitras, P., Trudel, L., Miller, P. \& Gu, C. M. Regulation of motilin release: studies with ex vivo perfused canine jejunum. Am. J. Physiol. 272, G4-G9 (1997).

69. Depoortere, I., Thijs, T., Thielemans, L., Robberecht, P. $\&$ Peeters, T. L. Interaction of the growth hormonereleasing peptides ghrelin and growth hormonereleasing peptide- 6 with the motilin receptor in the rabbit gastric antrum. J. Pharmacol. Exp. Ther. 305 660-667 (2003).

70. Gutierrez, J. A. et al. Ghrelin octanoylation mediated by an orphan lipid transferase. Proc. Natl Acad. Sci. USA 105, 6320-6325 (2008).

71. Muller, T. D. et al. Ghrelin. Mol. Metab. 4, 437-460 (2015).

72. Deloose, E., Vos, R., Corsetti, M., Depoortere, I. \& Tack, J. Endogenous motilin, but not ghrelin plasma levels fluctuate in accordance with gastric phase III activity of the migrating motor complex in man. Neurogastroenterol. Motil. 27, 63-71 (2015).

73. Sjolund, K., Ekman, R. \& Wierup, N. Covariation of plasma ghrelin and motilin in irritable bowel syndrome. Peptides 31, 1109-1112 (2010).

74. Johnson, L. R. Gastrointestinal hormones and their functions. Annu. Rev. Physiol. 39, 135-158 (1977)

75. Lee, K. Y., Kim, M. S. \& Chey, W. Y. Effects of a meal and gut hormones on plasma motilin and duodena motility in dog. Am. J. Physiol. 238, G280-G283 (1980).

76. Katsuura, G., Asakawa, A. \& Inui, A. Roles of pancreatic polypeptide in regulation of food intake. Peptides 23, 323-329 (2002). 
77. Hall, K. E., Diamant, N. E., El-Sharkawy, T. Y. \& Greenberg, G. R. Effect of pancreatic polypeptide on canine migrating motor complex and plasma motilin. Am. J. Physiol. 245, G178-G185 (1983).

78. Janssens, J. et al. Pancreatic polypeptide is not involved in the regulation of the migrating motor complex in man. Regul. Pept. 3, 41-49 (1982).

79. Mitznegg, P. et al. Effect of secretin on plasma motilin in man. Gut 18, 468-471 (1977).

80. Donnelly, D. The structure and function of the glucagon-like peptide- 1 receptor and its ligands. Br. J. Pharmacol. 166, 27-41 (2012).

81. Hellstrom, P. M. et al. GLP-1 suppresses gastrointestinal motility and inhibits the migrating motor complex in healthy subjects and patients with irritable bowel syndrome. Neurogastroenterol. Motil. 20, 649-659 (2008)

82. Feighner, S. D. et al. Receptor for motilin identified in the human gastrointestinal system. Science $\mathbf{2 8 4}$, 2184-2188 (1999)

83. McKee, K. K. et al. Cloning and characterization of two human $G$ protein-coupled receptor genes (GPR38 and GPR39) related to the growth hormone secretagogue and neurotensin receptors. Genomics 46, 426-434 (1997)

84. Peeters, T. L., Bormans, V. \& Vantrappen, G. Comparison of motilin binding to crude homogenates of human and canine gastrointestinal smooth muscle tissue. Regul. Pept. 23, 171-182 (1988)

85. Depoortere, I., Peeters, T. L. \& Vantrappen, G. Motilin receptors of the rabbit colon. Peptides 12, 89-94 (1991).

86. Poitras, P. et al. Heterogeneity of motilin receptors in the gastrointestinal tract of the rabbit. Peptides 17 , 701-707 (1996)

87. Van Assche, G., Depoortere, I. \& Peeters, T. L. Localization of motilin binding sites in subcellular fractions from rabbit antral and colonic smooth muscle tissue. Regul. Pept. 77, 89-94 (1998).

88. Miller, P. et al. Motilin receptors in the human antrum. Am. J. Physiol. Gastrointest. Liver Physiol. 278 G18-G23 (2000)

89. Miller, P., Trudel, L., St-Pierre, S., Takanashi, H. \& Poitras, P. Neural and muscular receptors for motilin in the rabbit colon. Peptides 21, 283-287 (2000).

90. Matsuura, B., Dong, M., Naik, S., Miller, L. J. \& Onji, M. Differential contributions of motilin receptor extracellular domains for peptide and non-peptidyl agonist binding and activity. J. Biol. Chem. 281 12390-12396 (2006).

91. Matsuura, B., Dong, M. \& Miller, L. J. Differential determinants for peptide and non-peptidyl ligand binding to the motilin receptor. Critical role of second extracellular loop for peptide binding and action. J. Biol. Chem. 277, 9834-9839 (2002)

92. Xu, L. et al. Motilin and erythromycin-A share a common binding site in the third transmembrane segment of the motilin receptor. Biochem. Pharmacol. 70, 879-887 (2005)

93. Mitselos, A., Vanden Berghe, P., Peeters, T. L. \& Depoortere, I. Differences in motilin receptor desensitization after stimulation with motilin or motilides are due to alternative receptor trafficking. Biochem. Pharmacol. 75, 1115-1128 (2008).

94. Mitselos, A., Peeters, T. L. \& Depoortere, I. Desensitization and internalization of the human motilin receptor is independent of the C-terminal tail. Peptides 29, 1167-1175 (2008)

95. Smith, J. S. \& Rajagopal, S. The $\beta$-arrestins: multifunctional regulators of $G$ protein-coupled receptors. J. Biol. Chem. 291, 8969-8977 (2016).

96. Thielemans, L. et al. Desensitization of the human motilin receptor by motilides. J. Pharmacol. Exp. Ther. 313, 1397-1405 (2005).

97. Christofides, N. D., Modlin, I. M., Fitzpatrick, M. L. \& Bloom, S. R. Effect of motilin on the rate of gastric emptying and gut hormone release during breakfast. Gastroenterology 76, 903-907 (1979).

98. Xynos, E. et al. Erythromycin accelerates delayed gastric emptying of solids in patients after truncal vagotomy and pyloroplasty. Eur. J. Surg. 158 407-411 (1992)

99. Urbain, J. L. et al. Intravenous erythromycin dramatically accelerates gastric emptying in gastroparesis diabeticorum and normals and abolishes the emptying discrimination between solids and liquids. J. Nucl. Med. 31, 1490-1493 (1990).

100. Tack, J. et al. Effect of erythromycin on gastric motility in controls and in diabetic gastroparesis. Gastroenterology 103, 72-79 (1992).
101. Achem-Karam, S. R., Funakoshi, A., Vinik, A. I. \& Owyang, C. Plasma motilin concentration and interdigestive migrating motor complex in diabetic gastroparesis: effect of metoclopramide. Gastroenterology 88, 492-499 (1985)

102. Annese, V. et al. Erythromycin accelerates gastric emptying by inducing antral contractions and improved gastroduodenal coordination. Gastroenterology 102, 823-828 (1992).

103. Bruley des Varannes, S. et al. Erythromycin enhances fasting and postprandial proximal gastric tone in humans. Gastroenterology 109, 32-39 (1995).

104. Coulie, B., Tack, J., Peeters, T. \& Janssens, J. Involvement of two different pathways in the motor effects of erythromycin on the gastric antrum in humans. Gut 43, 395-400 (1998).

105. Deloose, E., Janssen, P., Depoortere, I. \& Tack, J. The migrating motor complex: control mechanisms and its role in health and disease. Nat. Rev. Gastroenterol. Hepatol. 9, 271-285 (2012).

106. Deloose, E. et al. The motilin receptor agonist erythromycin stimulates hunger and food intake through a cholinergic pathway. Am. J. Clin. Nutr. 103 730-737 (2016)

107. Zhao, D. et al. The motilin agonist erythromycin increases hunger by modulating homeostatic and hedonic brain circuits in healthy women: a randomized, placebo-controlled study. Sci. Rep. 8, 1819 (2018).

108. Van Assche, G., Depoortere, I., Thijs, T., Janssens, J. J. $\&$ Peeters, T. L. Concentration-dependent stimulation of cholinergic motor nerves or smooth muscle by [Nle13]motilin in the isolated rabbit gastric antrum. Eur J. Pharmacol. 337, 267-274 (1997).

109. Dass, N. B. et al. The rabbit motilin receptor: molecula characterisation and pharmacology. Br. J. Pharmacol. 140, 948-954 (2003).

110. Broad, J. et al. Regional- and agonist-dependent facilitation of human neurogastrointestinal functions by motilin receptor agonists. Br. J. Pharmacol. 167 763-774 (2012).

111. Huang, J. et al. Signaling pathways mediating gastrointestinal smooth muscle contraction and MLC20 phosphorylation by motilin receptors. Am. J. Physiol. Gastrointest. Liver Physiol. 288, G23-G31 (2005).

112. Suzuki, A. et al. Molecular identification of GHS-R and GPR38 in Suncus murinus. Peptides 36, 29-38 (2012).

113. Javid, F. A. et al. Anti-emetic and emetic effects of erythromycin in Suncus murinus: role of vagal nerve activation, gastric motility stimulation and motilin receptors. Eur. J. Pharmacol. 699, 48-54 (2013).

114. Mathis, C. \& Malbert, C. H. Erythromycin gastrokinetic activity is partially vagally mediated. Am. J. Physiol. 274, G80-G86 (1998)

115. Depoortere, I., Van Assche, G. \& Peeters, T. L. Distribution and subcellular localization of motilin binding sites in the rabbit brain. Brain Res. $\mathbf{7 7 7}$ 103-109 (1997)

116. Thielemans, L., Depoortere, I., Van Assche, G., Bender, E. \& Peeters, T. L. Demonstration of a functional motilin receptor in TE671 cells from human cerebellum. Brain Res. 895, 119-128 (2001).

117. Kai, Y., Kawatani, H., Yajima, H. \& Itoh, Z. Studies on peptides. LV. Total synthesis of porcine motilin, a gastric motor activity stimulating polypeptide. Chem. Pharm. Bull. 23, 2346-2352 (1975).

118. Itoh, Z. et al. Motilin-induced mechanical activity in the canine alimentary tract. Scand. J. Gastroenterol. Suppl. 39, 93-110 (1976)

119. Boldyreff, W. Le travail periodique de l'appareil digestif endehors de la digestion [French]. Am. J. Physiol. 217 1757-1763 (1905).

120. Carlson, A. A study of the mechanisms of the hunge contractions of the empty stomach by experiments on dogs. Am. J. Physiol. 32, 369-388 (1913).

121. Szurszewski, J. H. A migrating electric complex of canine small intestine. Am. J. Physiol. 217, 1757-1763 (1969).

122. Code, C. F. \& Marlett, J. A. The interdigestive myo-electric complex of the stomach and small bowel of dogs. J. Physiol. 246, 289-309 (1975).

123. De Wever, I., Eeckhout, C., Vantrappen, G. \& Hellemans, J. Disruptive effect of test meals on interdigestive motor complex in dogs. Am. J. Physiol. 235, E661-E665 (1978)

124. Suzuki, H. et al. Effect of duodenectomy on gastric motility and gastric hormones in dogs. Ann. Surg. 233, 353-359 (2001).

125. Mondal, A. et al. Coordination of motilin and ghrelin regulates the migrating motor complex of gastrointestinal motility in Suncus murinus.
Am. J. Physiol Gastrointest Liver Physiol. 302 G1207-G1215 (2012).

126. Dent, J., Dodds, W. J., Sekiguchi, T., Hogan, W. J. \& Arndorfer, R. C. Interdigestive phasic contractions of the human lower esophageal sphincter. Gastroenterology 84, 453-460 (1983).

127. Janssens, J., Annese, V. \& Vantrappen, G. Bursts of non-deglutitive simultaneous contractions may be a normal oesophageal motility pattern. Gut 34 , 1021-1024 (1993).

128. Domschke, W., Lux, G., Mitznegg, P., Rosch, W. ¿ Domschke, S. Endogenous motilin and lowe esophageal sphincter pressure in man: clue to an association. Acta Hepatogastroenterol. (Stuttg.) 23 274-275 (1976).

129. Pennathur, A., Cioppi, M., Fayad, J. B. \& Little, A. G. Erythromycin, motilin, and the esophagus. Surgery 114, 295-298 (1993)

130. Korimilli, A. \& Parkman, H. P. Effect of atilmotin, a motilin receptor agonist, on esophageal, lower esophageal sphincter, and gastric pressures. Dig. Dis. Sci. 55, 300-306 (2010)

131. Lux, G. et al. Intravenous 13-Nle-motilin increases the human lower esophageal sphincter pressure. Scand. J. Gastroenterol. Suppl. 39, 75-79 (1976).

132. Tzovaras, G., Xynos, E., Chrysos, E., Mantides, A \& Vassilakis, J. S. The effect of intravenous erythromycin on esophageal motility in healthy subjects. Am. J. Surg. 171, 316-319 (1996)

133. Pennathur, A. et al. Erythromycin strengthens the defective lower esophageal sphincter in patients with gastroesophageal reflux disease. Am. J. Surg. 167 169-172 (1994).

134. Chrysos, E. et al. Erythromycin enhances oesophagea motility in patients with gastro-oesophageal reflux. ANZ J. Surg. 71, 98-102 (2001).

135. Janssen, P. et al. Review article: the role of gastric motility in the control of food intake. Aliment Pharmacol. Ther. 33, 880-894 (2011).

136. Cuomo, R. et al. Influence of motilin on gastric fundus tone and on meal-induced satiety in man: role of cholinergic pathways. Am. J. Gastroenterol. 101 804-811 (2006)

137. Tack, J., Caenepeel, P., Piessevaux, H., Cuomo, R. \& Janssens, J. Assessment of meal induced gastric accommodation by a satiety drinking test in health and in severe functional dyspepsia. Gut $\mathbf{5 2}$, 1271-1277 (2003)

138. Tack, J., Piessevaux, H., Coulie, B., Caenepeel, P. \& Janssens, J. Role of impaired gastric accommodation to a meal in functional dyspepsia. Gastroenterology 115, 1346-1352 (1998).

139. Kamerling, I. M. et al. Motilin effects on the proximal stomach in patients with functional dyspepsia and healthy volunteers. Am. J. Physiol. Gastrointest. Liver Physiol. 284, G776-G781 (2003).

140. Ruppin $\mathrm{H}$. et al. Effects of 13-nle-motilin in maninhibition of gastric evacuation and stimulation of pepsin secretion. Scand. J. Gastroenterol. 10, 199-202 (1975).

141. Strunz, U. et al. Gastroduodenal motor response to natural motilin and synthetic position 13-substituted motilin analogues: a comparative in vitro study. Scand. J. Gastroenterol. 11, 199-203 (1976).

142. Luttikhold, J. et al. Review article: the role of gastrointestinal hormones in the treatment of delayed gastric emptying in critically ill patients. Aliment. Pharmacol. Ther. 38, 573-583 (2013).

143. De Smet, B. \& Depoortere, I. Motilin and ghrelin as prokinetic drug targets. Pharmacol. Ther. 123 207-223 (2009).

144. Janssens, J. et al. Improvement of gastric emptying in diabetic gastroparesis by erythromycin. Preliminary studies. N. Engl. J. Med. 322, 1028-1031 (1990).

145. Erbas, T., Varoglu, E., Erbas, B., Tastekin, G. \& Akalin, S Comparison of metoclopramide and erythromycin in the treatment of diabetic gastroparesis. Diabetes Care 16, 1511-1514 (1993).

146. Richards, R. D., Davenport, K. \& McCallum, R. W. The treatment of idiopathic and diabetic gastroparesis with acute intravenous and chronic oral erythromycin Am. J. Gastroenterol. 88, 203-207 (1993).

147. Fiorucci, S. et al. Effect of erythromycin administration on upper gastrointestinal motility in scleroderma patients. Scand. J. Gastroenterol. 29, 807-813 (1994).

148. Stacher, G. et al. Erythromycin effects on gastric emptying, antral motility and plasma motilin and pancreatic polypeptide concentrations in anorexia nervosa. Gut 34, 166-172 (1993)

149. Minami, T., Nishibayashi, H., Shinomura, Y. \& 
idiopathic intestinal pseudo-obstruction J Gastroenterol. 31, 855-859 (1996).

150. Emmanuel, A. V., Shand, A. G. \& Kamm, M. A. Erythromycin for the treatment of chronic intestinal pseudo-obstruction: description of six cases with a positive response. Aliment. Pharmacol. Ther. 19, 687-694 (2004).

151. Mozwecz, H. et al. Erythromycin stearate as prokinetic agent in postvagotomy gastroparesis. Dig. Dis. Sci. 35, 902-905 (1990)

152. Janssen, P. et al. The relation between symptom improvement and gastric emptying in the treatment of diabetic and idiopathic gastroparesis. Am. J. Gastroenterol. 108, 1382-1391 (2013)

153. Boivin, M. A., Carey, M. C. \& Levy, H. Erythromycin accelerates gastric emptying in a dose-response manner in healthy subjects. Pharmacotherapy 23 5-8 (2003).

154. Sanger, G. J., Broad, J., Callaghan, B. \& Furness, J. B. Ghrelin and motilin control systems in GI physiology and therapeutics. Handb. Exp. Pharmacol. 239, 379-416 (2017)

155. Ter Beek, W. P. et al. Motilin receptor expression in smooth muscle, myenteric plexus, and mucosa of human inflamed and noninflamed intestine. Inflamm. Bowel Dis. 14, 612-619 (2008).

156. Venkatasubramani, N., Rudolph C. D \& Sood, M. R. Erythromycin lacks colon prokinetic effect in children with functional gastrointestinal disorders: a retrospective study. BMC Gastroenterol. 8, 38 (2008)

157. Jameson, J. S., Rogers, J., Misiewicz, J. J. Raimundo, A. H. \& Henry, M. M. Oral or intravenous erythromycin has no effect on human distal colonic motility. Aliment. Pharmacol. Ther. 6, 589-595 (1992).

158. Kamerling, I. M. et al. The effect of motilin on the rectum in healthy volunteers. $\mathrm{Br}$. J. Clin. Pharmacol. 55, 538-543 (2003)

159. Catnach, S. M. et al. Effect of oral erythromycin on gallbladder motility in normal subjects and subjects with gallstones. Gastroenterology 102, 2071-2076 (1992).

160. Luiking, Y. C. et al. Effects of motilin on human interdigestive gastrointestinal and gallbladder motility, and involvement of $5 \mathrm{HT} 3$ receptors. Neurogastroenterol. Motil. 14, 151-159 (2002).

161. Suzuki, H. et al. Motilin controls cyclic release of insulin through vagal cholinergic muscarinic pathways in fasted dogs. Am. J. Physiol. 274, G87-G95 (1998)

62. Suzuki, H. et al. Effect of motilin on endogenous release of insulin in conscious dogs in the fed state. Dig. Dis. Sci. 48, 2263-2270 (2003).

163. Ueno, N. et al. Erythromycin improves glycaemic control in patients with Type II diabetes mellitus. Diabetologia 43, 411-415 (2000).

164. Funakoshi, A., Schteingart, D. E. \& Vinik, A. I. Effect of insulin on motilin release in man. Tohoku J. Exp. Med. 152, 247-251 (1987).

165. Salminen, E. K. et al. Xylitol versus glucose: effect on the rate of gastric emptying and motilin, insulin, and gastric inhibitory polypeptide release. Am. J. Clin. Nutr. 49, 1228-1232 (1989).

166. Meyer-Gerspach, A. C. et al. Effects of caloric and noncaloric sweeteners on antroduodenal motility, gastrointestinal hormone secretion and appetiterelated sensations in healthy subjects. Am. J. Clin Nutr. 107, 707-716 (2018).

167. Steinert, R. E., Frey, F., Topfer, A., Drewe, J. \& Beglinger, C. Effects of carbohydrate sugars and artificial sweeteners on appetite and the secretion of gastrointestinal satiety peptides. Br. J. Nutr. 105 1320-1328 (2011).

168. Beaumont, W. Nutrition classics. Experiments and observations on the gastric juice and the physiology of digestion. By William Beaumont. Plattsburgh. Printed by F. P. Allen. 1833. Nutr. Rev. 35, 144-145 (1977).

169. Cannon, W. \& Washburn, A. An explanation of hunger. Am. J. Physiol. 29, 441-454 (1912).

170. Carlson, A. The Control of Hunger in Health and Disease (Univ. of Chicago Press, 1916).

171. Wren, A. M. et al. Ghrelin enhances appetite and increases food intake in humans. J. Clin. Endocrinol. Metab. 86, 5992 (2001).

172. Wren, A. M. et al. The novel hypothalamic peptide ghrelin stimulates food intake and growth hormone secretion. Endocrinology 141, 4325-4328 (2000).

173. Cummings, D. E. et al. A preprandial rise in plasma ghrelin levels suggests a role in meal initiation in humans. Diabetes 50, 1714-1719 (2001).

174. Cummings, D. E., Frayo, R. S., Marmonier, C. Aubert, R. \& Chapelot, D. Plasma ghrelin levels and hunger scores in humans initiating meals voluntarily without time- and food-related cues. Am. J. Physiol. Endocrinol. Metab. 287, E297-E304 (2004).

175. Deloose, E., Biesiekierski, J. R., Vanheel, H., Depoortere, I. \& Tack, J. Effect of motilin receptor activation on food intake and food timing. $\mathrm{Am}$. J. Clin. Nutr. 107, 537-543 (2018)

176. Tschop, M. et al. Circulating ghrelin levels are decreased in human obesity. Diabetes 50, 707-709 (2001).

177. Monti, V., Carlson, J. J., Hunt, S. C. \& Adams, T. D. Relationship of ghrelin and leptin hormones with body mass index and waist circumference in a random sample of adults. J. Am. Diet Assoc. 106, 822-828 (2006).

178. Avau, B. et al. Targeting extra-oral bitter taste receptors modulates gastrointestinal motility with effects on satiation. Sci. Rep. 5, 15985 (2015).

179. Labo, G., Bortolotti, M., Vezzadini, P., Bonora, G. \& Bersani, G. Interdigestive gastroduodenal motility and serum motilin levels in patients with idiopathic delay in gastric emptying. Gastroenterology 90, 20-26 (1986).

180. Deloose, E. et al. Higher plasma motilin levels in obese patients decrease after Roux-en- $Y$ gastric bypass surgery and regulate hunger. Gut 65, 1110-1118 (2016).

181. Bonora, G. et al. Interdigestive plasma motilin concentrations in aged adults. J. Gerontol. 41 , 723-726 (1986)

182. Frada, G. et al. Interdigestive gastroduodenal moto activity in the elderly. Ital. J. Gastroenterol. 16, 314 (1984).

183. Simren, M., Bjornsson, E. S. \& Abrahamsson, H. High interdigestive and postprandial motilin levels in patients with the irritable bowel syndrome. Neurogastroenterol. Motil. 17, 51-57 (2005).

184. Van Der Veek, P. P., Biemond, I. \& Masclee, A. A. Proximal and distal gut hormone secretion in irritable bowel syndrome. Scand. J. Gastroenterol. 41, 170-177 (2006)

185. Sjolund, K., Ekman, R., Akre, F. \& Lindner, P. Motilin in chronic idiopathic constipation. Scand. J. Gastroenterol 21, 914-918 (1986).

186. Preston, D. M., Adrian, T. E., Christofides, N. D., Lennard-Jones, J. E. \& Bloom, S. R. Positive correlation between symptoms and circulating motilin, pancreatic polypeptide and gastrin concentrations in functional bowel disorders. Gut 26, 1059-1064 (1985).

187. Perdikis, G. et al. Gastroesophageal reflux disease is associated with enteric hormone abnormalities. Am. J. Surg. 167, 186-191; discussion 191-192 (1994).

188. Kondo, Y, Torii, K Itoh, Z \& Omura, S. Erythromycin and its derivatives with motilin-like biological activities inhibit the specific binding of 125I-motilin to duodenal muscle. Biochem. Biophys. Res. Commun. 150 877-882 (1988)

189. Peeters, T. L. et al. The motilin antagonist ANQ-11125 blocks motilide-induced contractions in vitro in the rabbit. Biochem. Biophys. Res. Commun. 198, 411-416 (1994)

190. Pehl, C., Pfeiffer, A., Wendl, B., Stellwag, B. \& Kaess, H. Effect of erythromycin on postprandial gastroesophageal reflux in reflux esophagitis. Dis. Esophagus 10, 34-37 (1997).

191. Champion, G., Richter, J. E., Singh, S., Schan, C. \& Nellans, $\mathrm{H}$. Effects of oral erythromycin on esophageal $\mathrm{pH}$ and pressure profiles in patients with gastroesophageal reflux disease. Dig. Dis. Sci. 39, 129-137 (1994)

192. Chaussade, S., Michopoulos, S., Sogni, P., Guerre, J. \& Couturier, D. Motilin agonist erythromycin increases human lower esophageal sphincter pressure by stimulation of cholinergic nerves. Dig. Dis. Sci. 39 381-384 (1994)

193. Broad, J. \& Sanger, G. J. The antibiotic azithromycin is a motilin receptor agonist in human stomach: comparison with erythromycin. Br. J. Pharmacol. 168, 1859-1867 (2013).

194. Larson, J. M., Tavakkoli, A., Drane, W. E., Toskes, P. P. \& Moshiree, B. Advantages of azithromycin over erythromycin in improving the gastric emptying half-time in adult patients with gastroparesis. J. Neurogastroenterol. Motil. 16, 407-413 (2010).

195. Rohof, W. O. et al. Effect of azithromycin on acid reflux, hiatus hernia and proximal acid pocket in the postprandial period. Gut 61, 1670-1677 (2012)

196. Ray, W. A. et al. Oral erythromycin and the risk of sudden death from cardiac causes. N. Engl. J. Med. 351, 1089-1096 (2004).

197. Itoh, Z. \& Omura, S. Motilide, a new family of macrolide compounds mimicking motilin. Dig. Dis. Sci. 32, 915 (1987).
198. Verhagen, M. A. et al. Effects of a new motilide, ABT-229, on gastric emptying and postprandial antroduodenal motility in healthy volunteers. Aliment Pharmacol. Ther. 11, 1077-1086 (1997).

199. Clark, M. J. et al. Erythromycin derivatives ABT 229 and GM 611 act on motilin receptors in the rabbit duodenum. Clin. Exp. Pharmacol. Physiol. 26 242-245 (1999)

200. Cowles, V. E. et al. Effect of novel motilide ABT-229 versus erythromycin and cisapride on gastric emptying in dogs. J. Pharmacol. Exp. Ther. 293, 1106-1111 (2000).

201. Talley, N. J. et al. Failure of a motilin receptor agonist (ABT-229) to relieve the symptoms of functional dyspepsia in patients with and without delayed gastric emptying: a randomized double-blind placebocontrolled trial. Aliment. Pharmacol. Ther 14, 1653-1661 (2000).

202. Talley, N. J. et al. Effects of a motilin receptor agonist (ABT-229) on upper gastrointestinal symptoms in type 1 diabetes mellitus: a randomised, double blind, placebo controlled trial. Gut 49, 395-401 (2001).

203. Chen, C. L. et al. Efficacy of a motilin receptor agonist (ABT-229) for the treatment of gastro-oesophageal reflux disease. Aliment. Pharmacol. Ther. 16 749-757 (2002).

204. Sanger, G. J. Motilin, ghrelin and related neuropeptides as targets for the treatment of $\mathrm{Gl}$ diseases. Drug Discov. Today 13, 234-239 (2008).

205. Russo, A. et al. Effect of the motilin agonist KC 11458 on gastric emptying in diabetic gastroparesis. Aliment. Pharmacol. Ther. 20, 333-338 (2004)

206. McCallum, R. W., Cynshi, O. \& US Investigative Team. Efficacy of mitemcinal, a motilin agonist, on gastrointestinal symptoms in patients with symptoms suggesting diabetic gastropathy: a randomized, multi-center, placebo-controlled trial. Aliment. Pharmacol. Ther. 26, 107-116 (2007)

207. Heightman, T. D. et al. Identification of small molecule agonists of the motilin receptor. Bioorg. Med. Chem. Lett. 18, 6423-6428 (2008).

208. Westaway, S. M. et al. The discovery of biaryl carboxamides as novel small molecule agonists of the motilin receptor. Bioorg. Med. Chem. Lett. 18, 6429-6436 (2008).

209. Westaway, S. M. et al. Discovery of N-(3-fluorophenyl)1-[(4-([(3S)-3-methyl-1-piperazinyl]methyl)phenyl) acetyl]-4-piperidinamine (GSK962040), the first smal molecule motilin receptor agonist clinical candidate. J. Med. Chem. 52, 1180-1189 (2009).

210. Sanger, G. J. et al. GSK962040: a small molecule, selective motilin receptor agonist, effective as a stimulant of human and rabbit gastrointestinal motility. Neurogastroenterol. Motil. 21, 657-664 (2009).

211. Dukes, G. et al. Pharmacokinetics, safety/tolerability, and effect on gastric emptying of the oral motilin receptor agonist, GSK962040, in healthy male and female volunteers. Neurogastroenterol. Motil. 21, 84 (2009).

212. Dukes, G. et al. Safety/tolerability, pharmacokinetics (PK), and effect on gastric emptying (GE) with 14-days repeat oral dosing of the motilin receptor agonist, GSK962040, in healthy male and female volunteers. Neurogastroenterol Motil. 22, 14-15 (2010).

213. Chapman, M. J. et al. The effect of camicinal (GSK962040), a motilin agonist, on gastric emptying and glucose absorption in feed-intolerant critically ill patients: a randomized, blinded, placebo-controlled, clinical trial. Crit. Care 20, 232 (2016).

214. Hobson, R. et al. The effects of camicinal, a novel motilin agonist, on gastro-esophageal function in healthy humans-a randomized placebo controlled trial. Neurogastroenterol. Motil. 27, 1629-1637 (2015).

215. Deloose, E. et al. Manometric evaluation of the motilin receptor agonist camicinal (GSK962040) in humans. Neurogastroenterol. Motil. 30, e13173 (2018).

216. Marrinan, S. L. et al. A randomized, double-blind placebo-controlled trial of camicinal in Parkinson's disease. Mov. Disord. 33, 329-332 (2018).

217. Barton, M. E. et al. A randomized, double-blind, placebo-controlled phase II study (MOT114479) to evaluate the safety and efficacy and dose response of 28 days of orally administered camicinal, a motilin receptor agonist, in diabetics with gastroparesis. Gastroenterology 146, S20-S20 (2014).

218. Park, M. I. et al. Effect of atilmotin on gastrointestinal transit in healthy subjects: a randomized, placebocontrolled study. Neurogastroenterol. Motil. 18, 28-36 (2006)

219. Broad, J. et al. RQ-00201894: a motilin receptor agonist causing long-lasting facilitation of human 
gastric cholinergically-mediated contractions. J. Pharmacol. Sci. 130, 60-65 (2016).

220. Tsukamoto, K., Kuboyama, N., Yamano, M. Nakazawa, T. $\&$ Suzuki, T. In vitro pharmacological profile of SK-896, a new human motilin analogue. Pharmacology 60, 128-135 (2000).

221. Tsukamoto, K., Tagi, Y., Nakazawa, T. \& Takeda, M. Gastroprokinetic effect and mechanism of SK-896, a new motilin analogue, during the interdigestive period in conscious dogs. Pharmacology 63, 95-102 (2001).

222. Furuta, Y., Takeda, M., Nakayama, Y., Ito, M. \& Suzuki, Y. Effects of SK-896, a new human motilin analogue ([Leu 13]motilin-Hse), on postoperative ileus in dogs after laparotomy. Biol. Pharm. Bull. 25, 1063-1071 (2002)

223. Tsukamoto, K., Mizutani, M., Yamano, M., Tagi, Y. \& Takeda, M. The effect of SK-896 on post-operative ileus in dogs: gastrointestinal motility pattern and transit. Eur. J. Pharmacol. 401, 97-107 (2000).

224. Furuta, Y., Nakayama, Y., Nakashima, M. \& Suzuki, Y. Pharmacokinetic and pharmacodynamic studies of SK-896, a new human motilin analogue, in healthy male volunteers. Clin. Pharmacokinet. 42, 575-584 (2003).

225. Dennie, J. et al. A phase 1 study to assess the safety, tolerability, pharmacokinetics, and pharmacodynamics of single oral doses of DS-3801b, a motilin receptor agonist, in healthy subjects. J. Clin. Pharmacol. 57 , 1221-1230 (2017).

226. Sudo, H. et al. Oral administration of MA-2029, a novel selective and competitive motilin receptor antagonist, inhibits motilin-induced intestinal contractions and visceral pain in rabbits. Eur. $J$. Pharmacol. 581, 296-305 (2008).

227. Takanashi, H. et al. GM-109: a novel, selective motilin receptor antagonist in the smooth muscle of the rabbit small intestine. J. Pharmacol. Exp. Ther. 273, 624-628 (1995)

228. Venkova, K., Thomas, H., Fraser, G. L. \& Greenwood Van Meerveld, B. Effect of TZP-201, a novel motilin receptor antagonist, in the colon of the musk shrew (Suncus murinus). J. Pharm. Pharmacol. 61 367-373 (2009).

229. Kamerling, I. M. et al. Effects of a nonpeptide motilin receptor antagonist on proximal gastric motor function. Br. J. Clin. Pharmacol. 57, 393-401 (2004).

230. Ozaki, K. et al. An orally active motilin receptor antagonist, MA-2029, inhibits motilin-induced gastrointestinal motility, increase in fundic tone, and diarrhea in conscious dogs without affecting gastric emptying. Eur. J. Pharmacol. 615, 185-192 (2009).
231. Civalleri, D. et al. [Behavior of plasma pancreatic polypeptides and motilin in obese patients subjected to biliopancreatic bypass]. Boll. Soc. Ital. Biol. Sper. 56, 1929-1935 (1980).

232. Weiss, $\mathrm{H}$. et al. Effects of adjustable gastric banding on altered gut neuropeptide levels in morbidly obese patients. Obes. Surg. 11, 735-739 (2001).

\section{Acknowledgements}

E.D. is a postdoctoral fellow of the Fonds voor Wetenschappelijk Onderzoek (FWO).

Author contributions

E.D., I.D. and J.T. researched data for the article, made a substantial contribution to discussion of content and wrote, reviewed and/or edited the manuscript before submission. W.V. wrote, reviewed and/or edited the manuscript before submission.

\section{Competing interests}

The authors declare no competing interests.

Publisher's note

Springer Nature remains neutral with regard to jurisdictional claims in published maps and institutional affiliations. 